\title{
NIH emerges victorious in Bush's first budget
}

Irwin Goodwin, Washington

The US National Institutes of Health (NIH) emerged as the sole winner among federal science agencies in President George W. Bush's first budget request to Congress last week. The request calls for an overall $4 \%$ increase in public spending to a record $\$ 1.96$ trillion.

But several agencies, including the National Science Foundation (NSF), the Department of Energy (DoE), NASA and the Environmental Protection Agency (EPA), are left with no increases - and in some cases reductions - in funding.

The NIH is in line for a large funding boost, as expected (see Nature 409, 969; 2001). Its requested $13.8 \%$ increase of $\$ 2.8$ billion on its current budget of $\$ 20.3$ billion leaves it on track to double its 1998 appropriation by 2003 .

The NSF can only be envious. In September, Rita Colwell, the NSF's director, requested a $15 \%$ increase to the agency's $\$ 4.4$ billion

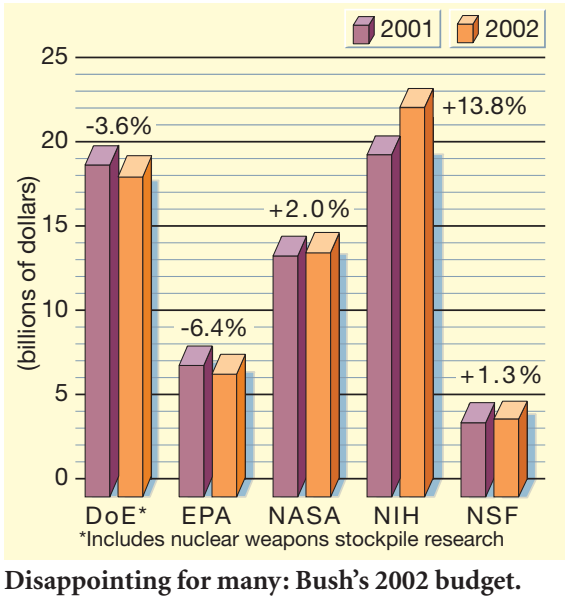

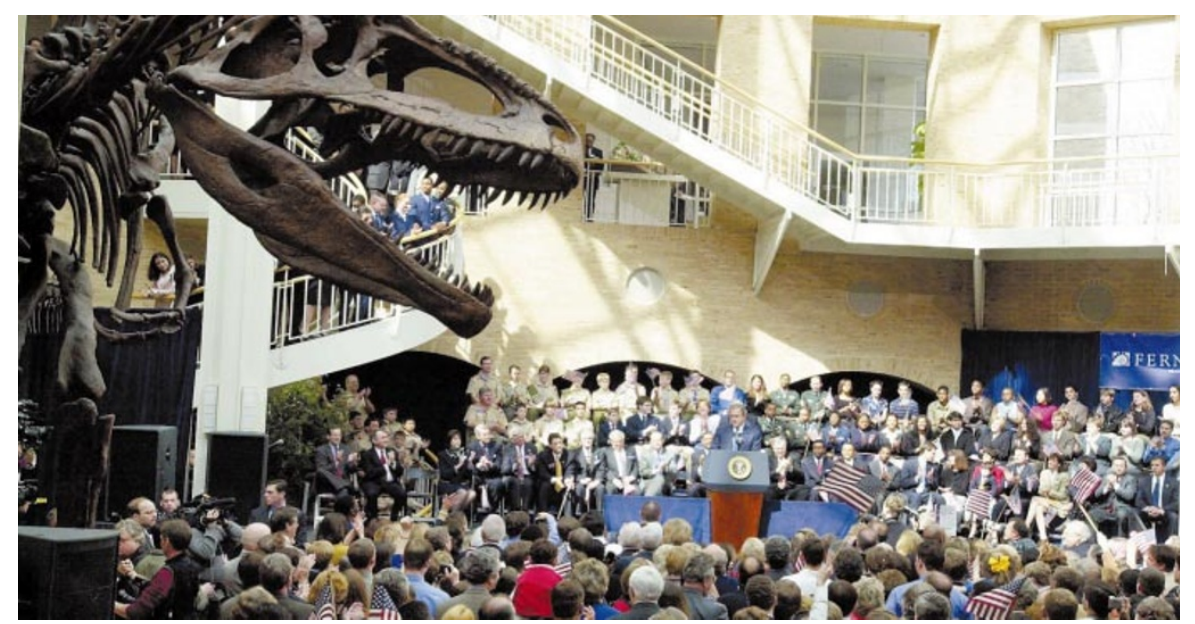

Bare bones of the budget: Bush enlists support for his spending plans at Fernbank Museum in Atlanta.

budget. But its ambitions to boost programmes in such areas as nanotechnology, terascale computers and earthquake simulation will be compromised by Bush's budget, which would provide only a $1.3 \%$ increase.

The DoE had also asked for a $15 \%$ increase on its $\$ 19.7$ billion budget. Instead it faces a cut of 3.6\%. Bush's 2002 blueprint also calls for increased spending on aid for energy-saving improvements to houses, tax credits for solar and renewable fuels, and some $\$ 275$ million extra for stewardship of the nuclear weapons stockpile.

The DoE had hoped to increase grants to university researchers and to fund more users of facilities in high-energy and nuclear physics, materials sciences and fusion research, as well as expanding its genome and bioengineering research at Los Alamos and Brookhaven. The proposed budget reduction puts paid to such plans, and is likely to postpone refurbishment at ageing national labo- ratories such as Los Alamos and Oak Ridge.

But one senior DoE official insists that its pledges to Europe's Large Hadron Collider, the high-energy accelerators at Fermilab, Brookhaven and Stanford, and the Spallation Neutron Source under construction at Oak Ridge in Tennessee, will not be affected.

NASA, slated for a $2 \%$ increase to $\$ 14.5$ billion, has been specifically told to cancel its Pluto-Kuiper Express and Solar Probe missions, largely to pay for overruns in the costs of the International Space Station, and to fund a more robust Mars exploration programme. Last week, the agency cancelled the $\mathrm{X}-33$ experimental space plane after investing $\$ 1.3$ billion over five years.

But the Bush budget statement is not the last word, says Representative Jim Walsh (Republican, New York), who chairs the House Appropriations Subcommittee. "Ultimately, the Congress will decide what is spent, and that's how it should be."

\section{Indian science benefits from sizeable funding increase}

\section{K. S. Jayaraman, New Delhi}

Indian science has received a funding boost of $11.7 \%$ in the annual budget announced last week. The big winners in the budget, which brings total science spending to 128.4 billion rupees (US $\$ 2.8$ billion), are

biotechnology, oceanography, and research into solar energy and traditional medicines.

Spending to rebuild the economy of Gujarat, shattered by the recent earthquake, has precluded an across-the-board increase for all ministries.

The Department of Science and Technology will receive an extra 100 million rupees for basic research and 250 million rupees for disaster-mitigation activities following the Gujarat quake.

Industrial research spending will increase by $5 \%$, and Ragunath Mashelkar, secretary for the Department of Scientific and Industrial Research, is encouraged by the provision of 500 million rupees for "new millennium technology initiatives" and tax relief for pharmaceutical companies entering biotech research.

Atomic energy, space and defence research, which account for the bulk of overall science spending in India, receive rises of $8.9 \%, 6.4 \%$ and $5.8 \%$, respectively. Biotechnology will get an extra $23 \%$, and spending on solar energy will more than triple to 1.74 billion rupees, some of which is earmarked for pilot studies towards a solar electric power plant to be built in the Rajasthan desert.

Funding for oceanographic research rises by $60 \%$, with money being provided for a joint venture with Russia for the design of unmanned submersibles. These are being developed as part of an Indian programme for recovering manganese nodules from the bottom of the Indian Ocean.

The increase in funding for the Department of Biotechnology is destined for projects in genomics, research into medicinal plants and the creation of an Institute of Bioresource and Sustainable Development.

The budget also provides for the creation of a Traditional Knowledge Digital Library to document traditional remedies something Mashelkar says may help tell patent officers worldwide about the existence of cures already known in India. 